\title{
WHITMAN, WARREN, AND THE LITERATURE OF DISCOVERY
}

\author{
WiLLIAM BeDFoRd CLARK
}

Having completed his stint as a Rhodes Scholar, Robert Penn Warren returned to the United States in 1930, and that same ominous year his new poem "Empire" appeared in the little magazine This Quarter. It represented at once a sharpening of his poetic skills and a broadening of the dominant concerns of his earlier Fugitive period. Though Warren in effect suppressed the poem by neglecting to include it in subsequent collections of his verse, "Empire" remains among the more creditable of his early works, and it is particularly remarkable in terms of the intertextual relationship it bears to the work of a poet whose name is seldom evoked in connection with Warren's own-Walt Whitman. "Empire" traces the westward course of discovery from the voyages of the Phoenicians, Greeks, and Romans to Europe's ultimate encounter with a New World of Edenic promise and beyond. Ostensibly, Warren's preColumbian explorers had traversed a flat, rectangular earth and did not suspect that "land and ocean bend / downward to make the long circuit home." They could not envision "the long way home" or the fact that "the world closes [upon itself] like a tired closed hand":

Then others came who knew; the man from Genoa knew on the high-pooped caraval.

Santa Maria. O white and virginal incredible shore where morning breakers ran!

Hendrick Hudson, icicles in his beard, northwest by west to the echo of a word.

India. By frozen coasts the bitten spume; passage to India, passage home. ${ }^{1}$

Nearly six decades earlier, Whitman had made the old call "passage to India" uniquely his own in his ecstatic poem by that title, and "Empire" is clearly the young Warren's skeptical response to his precursor's celebrative vision. For Whitman, "the strong light works of engineers"-technological advances in travel and communicationmade possible at last the physical completion of what Warren later called "the long circuit home," that linkage of West with East leading back upon itself to render the bifurcated globe one world whole again. The dream of Columbus, as Whitman ascribed it to him, had thus been more than vindicated, and Whitman's prophecy of a limitless future 
easily dwarfed the routinely nationalistic optimism of Joel Barlow's Columbiad. Indeed, Whitman's manic prediction of a cross-fertilization between the putatively rational West and the mystic East and the free giving and taking in marriage between all the world's races is enough to satisfy the tortured longings of today's most committed proponent of multiculturalism, but in Democratic Vistas, Whitman simultaneously posed the possibility that the millennarian dream might end in nightmare. At times, he wrote as if that dread possibility were more than likely. Everything depended upon an inner progress keeping pace with technological and scientific developments; it was poetry (in particular the vatic poetry Whitman favored) that must assume the vanguard in all future voyages of psychic discovery. Both poet and reader were called upon to assume an explicitly Columbian role, but I would suggest that Whitman's Browningesque "Prayer of Columbus" (in which he spoke covertly through an "impersonalized" but avowedly autobiographical persona) revealed the extent to which he was hoping against hope. To this ought to be added the vaporish affirmation at the conclusion of "A Thought of Columbus," according to Horace Traubel Whitman's final poem, written on his deathbed on the occasion of the fourth centenary of the Genoan's fateful encounter with the West Indies. What was it about the image of the broken Admiral, dependent upon a far distant future for justification, that so compelled Whitman's imagination, even as he prepared to launch upon his own final voyage beyond the limits of life itself? Would America in the next century stay the course he had charted to effect a "passage to more than India" and establish a homeland for the vagrant post-Cartesian self? Written a dozen years after the Great War and at the outset of the Depression, Warren's response took on a peculiar spin.

In "Empire," Warren de-romanticized the Age of Discovery by stressing the physical deprivations and untold deaths that were its human cost. Yet he openly envied the certitude and faith of those who undertook to explore the potential of a New World, however "horizonsick" they may have been, for Americans of the present age lacked the bearings that had guided their forebears. True, Whitman, in Democratic Vistas, had inveighed against the nation's "hollowness of heart" following the Civil War, and, even before that cataclysmic event, had angrily deplored America's perversion of its mission in his splendid malediction "Respondez!" Nonetheless, the troubles facing Americans at the conclusion of the Jazz Age were, as Warren presents them, not so much a result of neglecting the admonitions of the Good Gray Poet as a consequence of following his counsel too eagerly. Whitman, while making frequent cursory nods in the direction of the past, had urged us to live fully in the present with a confident eye cocked toward the future, whereas Warren lamented the fact that in these latter days "the quick / 
lack commerce with the [vital] dead" so that modern Man is a "Bastard to memory." Whitman had advocated a new sexual openness. For Warren, a latitudinarian erosion of traditional sexual mores led us to "spawn from no desire." Whitman sought to counter shame and dispel the sense of Original Sin, but when Warren described the contemporary American as a "spotless white / new lamb, got of no sin, born to no wrath, / no home, no repentance," he meant to suggest that in losing the awareness of our fallen nature we denatured ourselves.

My point is not simply to belabor the obvious differences that separate Whitman, who so painfully wanted to be his nation's acknowledged voice, from Warren, who somewhat reluctantly agreed to serve as the United States' first official Poet Laureate. In fact, I think those differences have been too often exaggerated. When Whitman passed strangers in the street, he did not always recognize worthy cameradoes saluting him with the gestures of a vaguely homoerotic freemasonry. On occasion, he encountered Baudelairean spectres, pounding the pavements of Broadway as surely as they would later creep through the Unreal Cities of Eliot and Warren. By the same token, Warren, particularly in his last phase, could record moments of cosmic consciousness that would have passed muster with Whitman's enthusiastic disciple Dr. Bucke. Both poets took America as their muse and saw poetry as the last best hope of bringing her home to herself. In his 1976 poem "Bicentennial," Warren might, as Victor Strandberg has noted, engage in a grim parody of Whitman's inclusive surveys of American occupations and preoccupations, ${ }^{2}$ but in so doing he implicitly revealed a residual susceptibility to his forerunner's stubborn nationalism, as well as a like appreciation for the imposing sublimity of the American landscape.

Admittedly, Whitman was not an important poet for Ransom and Tate, who presided over Warren's poetic novitiate, and Warren first began to master his craft at a time when modernist poetics looked back to the dense intellection of the Metaphysicals for inspiration. Questions of overt influence are one thing, however, and matters of subtle intertextual insemination are quite another, and we can now recognize the degree to which those two titans of high modernism, Pound and Eliot, bobbed in the wake of Whitman's passage. One need not subscribe to Harold Bloom's "anxiety of influence" thesis in all its Freudian particulars to see the even more crucial struggle with the Whitman legacy going on within the Warren canon. The fact that Warren did some laborious special pleading in an effort to restore the moribund reputation of Whittier (this year marks the centennial of that poet's death also-but where are the commemorative symposia?) is worthy of meditation when we consider how seldom Whitman's name turns up in Warren's essays or recorded conversations. ${ }^{3}$ Yet Warren's long poems have little enough to do with Snowbound. Rather, his celebrations of 
Audubon and Chief Joseph are, in their questing for national heroes and striving for an epic scope, startlingly Whitmanesque in conception if not realization, and in Brother to Dragons Warren displays a delight in raw Americana and raunchy Americanisms that suggests an instinctive, though hardly philosophical, kinship with old Walt. Philosophically, Warren always professed an affinity with anti-transcendentalists like Hawthorne and Melville, and it is perhaps telling that his most direct and detailed comments on Whitman occur in the course of his magisterial essay on Melville as poet.

Melville had the same tragic sense of life's moral ambiguities that formed the basis for Warren's vision. His religious doubts and yearnings mirrored Warren's own, and his misgivings about America's future following the Civil War seemed to Warren borne out by subsequent events in our national life. Still, Warren concedes that Whitman is "in general, the greater poet." ${ }^{4}$ Even so, Warren finds Melville's verse more compelling. Whitman's strategy is, Warren argues, a "synthetic" one. Whatever "tensions and contradictions" may lurk at the center of Whitman's poems are "absorbed, purged in the vivid overmastering immediacy" of his images ("MP," 817). Warren regards Melville in contrast as an "analytic" poet whose dialectical approach resists resolution: "Like all decent poetry, that of Melville aims at a moment of poise, of synthesis, but for him [these things] are hard won, and often incomplete or provisional." The "intensity and purity of feeling" in Whitman stand in opposition to the "complexity or painful richness of feeling" Warren values in Melville's better poems ("MP," 818). Whitman's Civil War poetry "moves toward ritual," while Melville's "moves toward tragedy" ("MP," 818).

Warren's critique of Whitman echoes that of the redoutable George Santayana, though Warren scrupulously admits that the sardonic philosopher ignored "the whole truth of Whitman" ("MP," 819). Still, the problem with "pure" synthesis is that it too quickly ceases to go anywhere. In the urge to unify the disparate Many in the sublime One, Whitman was guilty of devaluing the claims of conflicting distinctions. (Indeed, we might recall his readiness to embrace, blithely, the myriad contradictions in himself, which is, of course, tantamount to denying their reality.) On the other hand, Melville, whose "yearning for absolutes" may well have rivaled Whitman's, remained acutely sensitive to the "relativisms of experience." Unlike the Sage of Camden, Melville was "a mystic who hated mysticism" ("MP," 821-822).

To better grasp what Warren is up to here, we might return at this point to the metaphors of voyaging and discovery. In "Passage to India," Whitman urged us on to unbounded explorations of selfhood out of a confident assurance that all seas are "the seas of God." Toward the end, Melville seems to have arrived at a similar conclusion, and 
Warren winds up saying much the same thing in his later poetry, but only after many halts and starts. It is hardly coincidental that Warren's finest piece of practical criticism is his famous reading of Coleridge's Ancient Mariner, in which the beleagured voyager's final, "synthetic" vision is paid for by a stffering and estrangement that cannot be denied. ${ }^{5}$ Warren had heede ${ }^{-1}$ the lesson Dante had taught Eliot earlierthat the way up started at the bottom. Whitman climbed to the crow's nest before he had full command of his sea-legs. He took premature, visionary possession of the New World, but that world, in all its troublesome particulars, remained unsubdued. For a poet like Warren, for whom the writer's vision had to be "earned" and periodically reearned, Whitman represented something of a daring cartographer who might map the way but only in the most generalized terms. Lest I be thought irreverent on this occasion dedicated to Whitman's memory, I would simply remind my audience of the number of his committed admirers who persist in their preference for the earlier editions of Leaves of Grass - at least in part on account of their rough vigor and what Warren would call their "impurity," which is not surprising when one considers how much Whitman's best commentators owe, consciously or otherwise, to the New Critical tenets Warren did so much to popularize.

Yet if Warren was more comfortable with and appreciative of Melville, by his own admission the lesser poet, it was Whitman against whom he always implicitly defined himself, for like Whitman he took the promise of the American experiment as his perennial (one might almost say obsessive) theme. In Brother to Dragons, Warren's Thomas Jefferson, that prototypical definer of this nation's inner and outer aspirations, recalls his initial dream of America's unfolding westward destiny in these unmistakably Whitmanesque terms:

I saw all,

Swale and savannah and the tulip-tree

Immortally blossoming in May,

Hawthorn and haw,

Valleys extended and prairies idle and the land's

Long westward langour lifting toward the flaming escarpment at the end of the day.

Saw the sad bison lick the outstretched hand,

And on the western rock, wracked in the clang and smother,

The black seal barks, and loves us, knowing we will come.

For the wind is steady, and the moon rides gold,

Suns execute their arrogant processional

Of deep delight, and the illimitable glitter

Of distance dazzles to our human fulfillment. ${ }^{6}$

However, Warren's Jefferson curses his "dream" of "human fulfillment" in the Garden of the New World when he finds his optimistic faith in humankind's innate goodness shattered by the discovery of our unregenerate propensity for blind, irrational violence. The future, he 
learns, holds no guarantees; meliorism is a self-destructive mirage. Jefferson despairs of America, but as is so often the case his despair springs from an inverted pride. ${ }^{7}$ It is only when he comes to terms with the sinister shadows that haunt the heart of his dream that he can take a realistic joy in the possibilities that persist in spite of the heavy liabilities of human nature. What remains, he realizes, is a "better" dream, because it denies the seductive comfort of denial. Warren's Jefferson, no less than the vatic protagonist of "Passage to India," ends "in joy," in a reaffirmation of America's unique destiny, but his celebration is tempered by a chastened knowledge that our "human fulfillment" depends upon a recognition of the fact that the American Eden is less a garden than a jungle, as subject to the brutalities of history as the Old World ever was, and presided over by an Adam and Eve who are anything but innocent.

Whitman knew these things, but in his most characteristic poetry so de-emphasized them as to absorb the darkness in a blinding light. Perhaps the very intensity of Whitman's determination to accentuate the positive speaks to the degree of bitter discovery that burdened him. I leave that question to those better equipped to wrestle with it. What is clear is that Warren felt as strong a compulsion to sing and celebrate "These States" as did his bearded elder. Perhaps poetry can point us toward "the long way home," but landfall still lies far to the west.

\section{Texas AEM University}

\section{NOTES}

1 Robert Penn Warren, “Empire,” This Quarter 3:1 (1930), 168-169.

2 Victor Strandberg, The Poetic Vision of Robert Penn Warren (Lexington: University Press of Kentucky, 1977), 118.

3 See Robert Penn Warren's Fohn Greenleaf Whittier's Poetry: An Appraisal and a Selection (Minneapolis: University of Minnesota Press, 1971), especially the Introduction, 3-63.

4 Robert Penn Warren, “Melville's Poems," Southern Review n.s. 3 (1967), 817. Hereafter cited parenthetically in the text as "MP."

5 Robert Penn Warren, “A Poem of Pure Imagination," Kenyon Review 9 (1946), 391-427.

6 Robert Penn Warren, Brother to Dragons (New York: Random House, 1953), 11.

7 I have discussed the plight of Jefferson in the poem at some length in " 'Canaan's Grander Counterfeit': Jefferson and America in Brother to Dragons," Renascence 30 (1978), 171-178. Reprinted in Robert Penn Warren's Brother to Dragons: A Discussion, ed. James A. Grimshaw, Jr. (Baton Rouge: Louisiana State University Press, 1983), 144152. 